\title{
Hirsutenols D, E and F, New Sesquiterpenes from the Culture Broth of Stereum hirsutum
}

\author{
Nam-Hee Yoo, Jong-Pyung Kim, Bong-Sik Yun, In-Ja Ryoo, In-Kyoung Lee, \\ Eui-Soo Yoon, Hiroyuki Koshino, Ick-Dong Yoo
}

Received: September 20, 2005 / Accepted: January 6, 2006

(C) Japan Antibiotics Research Association

\begin{abstract}
New sesquiterpenes, hirsutenols $D \sim F$, were isolated from the fermentation broth of Stereum hirsutum, and their structures were determined on the basis of various spectroscopic analyses. Hirsutenols E and F showed significant scavenging activity against superoxide anion radicals with $\mathrm{EC}_{50}$ values of 1.62 and $0.39 \mathrm{mM}$, respectively.
\end{abstract}

Keywords Stereum hirsutum, hirsutenols, antioxidant, sesquiterpene

Free radicals have been known to be involved in various pathological processes represented by the pathogenesis of diseases such as myocardial and cerebral ischemia, atherosclerosis, diabetes, rheumatoid arthritis, cancerinitiation and aging processes [1 3]. Thus, free radical scavengers are considered to be protective agents against these diseases. Stereum hirsutum is a producer of various tricyclic sesquiterpenes and we have reported the isolation of antioxidant substances hirsutenols $\mathrm{A} \sim \mathrm{C}[4]$ and sterins $\mathrm{A} \sim \mathrm{C}[5,6]$ from the fermentation broth of this strain. Further investigation on the metabolites of $S$. hirsutum has resulted in isolation of new sesquiterpenes designated hirsutenols D (1), E (2) and F (3). We herein report the isolation, physico-chemical properties, structure determination and free radical scavenging activity of these compounds.
A strain of $S$. hirsutum grown on potato dextrose agar medium was used to inoculate a $500 \mathrm{ml}$ Erlenmeyer flask containing $100 \mathrm{ml}$ of the seed medium consisting of yeast extract $0.4 \%$, malt extract $1.0 \%$ and glucose $0.4 \%(\mathrm{pH} 6.0$ before sterilization). The flask was shaken on a rotary shaker for four days at $27^{\circ} \mathrm{C}$. The seed culture was transferred into a 5-liter jar fermenter containing 3 liters of the above medium for production of hirsutenols, and cultivation was carried out at $28^{\circ} \mathrm{C}$ for 12 days with aeration of 2 liters/minute and agitation of $250 \mathrm{rpm}$.

The fermentation broth (30 liters) was separated into supernatant and mycelia by centrifugation. The supernatant was applied to a Diaion HP-20 column, and the column was washed with $30 \%$ aqueous $\mathrm{MeOH}$ and eluted with $70 \%$ aqueous $\mathrm{MeOH}$. After evaporation of the $70 \%$ aqueous $\mathrm{MeOH}$ eluent in vacuo, the resultant residue was partitioned between ethyl acetate and water. The EtOAcsoluble portion was subjected to a column of silica gel and eluted with $\mathrm{CHCl}_{3}: \mathrm{MeOH}(30: 1 \sim 1: 1$, stepwise) to give active fractions. The antioxidative fractions were concentrated and applied to a Sephadex LH-20 column, which was developed with $\mathrm{MeOH}$. The eluate was further purified by reverse-phase HPLC with ODS column (YMC, $250 \times 20 \mathrm{~mm}$; flow rate, $7 \mathrm{ml} /$ minute) eluting with $15 \%$ aqueous $\mathrm{MeOH}$ to give 1 (r.t. 27 minutes, $11.1 \mathrm{mg}$ ) and eluting with $25 \%$ aqueous acetonitrile to afford 2 (r.t. 42 minutes, $1.2 \mathrm{mg}$ ) and $\mathbf{3}$ (r.t. 14 minutes, $4.1 \mathrm{mg}$ ).

The physico-chemical properties of hirsutenols D, E and $\mathrm{F}$ are summarized in Table 1, and ${ }^{1} \mathrm{H}$ and ${ }^{13} \mathrm{C}$ NMR spectral
I.-D. Yoo (Corresponding author), N.-H. Yoo, J.-P. Kim, B.-S. Yun, I.-J. Ryoo, I.-K. Lee: Laboratory of Antioxidants, Korea Research Institute of Bioscience and Biotechnology, Daejeon 305333, Korea, E-mail: idyoo@kribb.re.kr
E.-S. Yoon: Department of Biology, Kongju National University, Kongju 314-701, Korea

H. Koshino: Molecular Characterization Team, RIKEN, Hirosawa 2-1, Wako, Saitama 351-0198, Japan 
Table 1 Physico-chemical properties of hirsutenols D (1), E (2) and F (3)

\begin{tabular}{|c|c|c|c|}
\hline & 1 & 2 & 3 \\
\hline Appearance & Yellow powder & Yellow powder & Yellow powder \\
\hline$[\alpha]_{D}^{20}$ & +12.5 (c 0.09, MeOH) & $+11(c 0.09, \mathrm{MeOH})$ & -30 (c $0.1, \mathrm{MeOH})$ \\
\hline Molecular formular & $\mathrm{C}_{15} \mathrm{H}_{18} \mathrm{O}_{5}$ & $\mathrm{C}_{15} \mathrm{H}_{24} \mathrm{O}_{3}$ & $\mathrm{C}_{15} \mathrm{H}_{18} \mathrm{O}_{4} \mathrm{~S}$ \\
\hline Molecular weight & 278 & 252 & 294 \\
\hline \multicolumn{4}{|l|}{ HR-FAB-MS m/z } \\
\hline Found & $301.1057\left(\mathrm{M}+\mathrm{Na}^{+}\right)$ & & $295.1001\left(\mathrm{M}+\mathrm{H}^{+}\right)$ \\
\hline Calcd. & 301.1052 & & 295.1004 \\
\hline \multicolumn{4}{|l|}{ HR-ESI-MS m/z } \\
\hline Found & & $275.1655\left(\mathrm{M}+\mathrm{Na}^{+}\right)$ & \\
\hline Calcd. & & 275.1623 & \\
\hline$U V \lambda_{\max } n m$ (in $\mathrm{MeOH}$ ) & $234(\varepsilon 2.83)$ & 221 ( $\varepsilon$ 2.89) & 245 ( $\varepsilon$ 3.19) \\
\hline $\mathrm{IR} v_{\max } \mathrm{cm}^{-1}(\mathrm{KBr})$ & $3368,2926,2855$ & 3371, 2926, 2856, & $3369,2927,1746$ \\
\hline TLC (Rf values) ${ }^{a}$ & 0.44 & $\begin{array}{l}1003,1504,1102 \\
0.45\end{array}$ & 0.48 \\
\hline HPLC Rt (min) ${ }^{b}$ & 7.27 & 16.58 & 5.03 \\
\hline Soluble & $\mathrm{MeOH}, \mathrm{DMSO}$ & $\mathrm{MeOH}, \mathrm{DMSO}$ & $\mathrm{MeOH}, \mathrm{DMSO}$ \\
\hline Insoluble & Hexane, water & Hexane, water & Hexane, water \\
\hline
\end{tabular}

a Silica gel plate (Silica gel 60 F254, Merck), chloroform - methanol (7: 1).

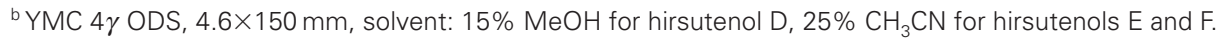

Table $2{ }^{1} \mathrm{H}$ and ${ }^{13} \mathrm{C}$ NMR spectral data of hirsutenols $\mathrm{D}(\mathbf{1}), \mathrm{E}(\mathbf{2})$ and $\mathrm{F}(\mathbf{3})$ in $\mathrm{CD}_{3} \mathrm{OD}$

\begin{tabular}{|c|c|c|c|c|c|c|}
\hline \multirow{2}{*}{$\begin{array}{c}\text { Canbon } \\
\text { No. }\end{array}$} & \multicolumn{2}{|r|}{1} & \multicolumn{2}{|r|}{2} & \multicolumn{2}{|r|}{3} \\
\hline & $\delta_{\mathrm{C}}$ & $\delta_{\mathrm{H}}$ & $\delta_{\mathrm{C}}$ & $\delta_{\mathrm{H}}$ & $\delta_{\mathrm{C}}$ & $\delta_{\mathrm{H}}$ \\
\hline \multirow[t]{2}{*}{1} & 76.7 & $4.60(1 \mathrm{H}, \mathrm{s})$ & 45.5 & $1.23(1 \mathrm{H}, \mathrm{m})$ & 76.3 & $4.59(1 \mathrm{H}, \mathrm{d}, J=2.4 \mathrm{~Hz})$ \\
\hline & & & & $1.94(1 \mathrm{H}, \mathrm{m})$ & & \\
\hline 2 & 185.9 & & 49.8 & $2.61(1 \mathrm{H}, \mathrm{dd}, J=9.6,19.2 \mathrm{~Hz})$ & 181.2 & \\
\hline 3 & 58.6 & & 61.1 & $1.46(1 \mathrm{H}, \mathrm{d}, J=7.2 \mathrm{~Hz})$ & 56.4 & \\
\hline 4 & 149.5 & & 80.0 & $3.76(1 \mathrm{H}, \mathrm{dd}, J=7.2 \mathrm{~Hz})$ & 60.9 & $2.62(1 \mathrm{H}, \mathrm{brdd}, J=3.6,2.4 \mathrm{~Hz})$ \\
\hline 5 & 205.2 & & 66.9 & $3.27(1 \mathrm{H}, \mathrm{m})$ & 216.0 & \\
\hline 6 & & & 69.6 & & 45.9 & $2.80(2 \mathrm{H}, \mathrm{s})$ \\
\hline 7 & 87.7 & & 55.8 & & 93.3 & \\
\hline \multirow[t]{2}{*}{8} & 72.4 & $4.44(1 \mathrm{H}, \mathrm{s})$ & 42.9 & $1.35(1 \mathrm{H}, \mathrm{m})$ & 49.2 & $3.55(1 \mathrm{H}, \mathrm{br} \mathrm{s})$ \\
\hline & & & & $1.75(1 \mathrm{H}, \mathrm{dd}, J=10.2,13.8 \mathrm{~Hz})$ & & \\
\hline 9 & 145.0 & & 46.1 & $2.82(1 \mathrm{H}, \mathrm{m})$ & 144.0 & \\
\hline \multirow[t]{2}{*}{10} & 208.5 & & 46.4 & $1.25(1 \mathrm{H}, \mathrm{m})$ & 206.9 & \\
\hline & & & & $1.95(1 \mathrm{H}, \mathrm{m})$ & & \\
\hline 11 & 54.8 & & 48.5 & & 55.8 & \\
\hline 12 & 20.3 & $1.02(3 \mathrm{H}, \mathrm{s})$ & 68.7 & $3.26(2 \mathrm{H}, \mathrm{m})$ & 21.5 & $1.11(3 \mathrm{H}, \mathrm{s})$ \\
\hline 13 & 23.8 & $1.11(3 \mathrm{H}, \mathrm{s})$ & 24.4 & $1.04(3 \mathrm{H}, \mathrm{s})$ & 23.7 & $1.21(3 \mathrm{H}, \mathrm{s})$ \\
\hline 14 & 21.1 & $1.52(3 \mathrm{H}, \mathrm{s})$ & 13.4 & $1.28(3 \mathrm{H}, \mathrm{s})$ & 13.6 & $1.23(3 \mathrm{H}, \mathrm{s})$ \\
\hline \multirow[t]{2}{*}{15} & 122.4 & $5.72(1 \mathrm{H}, \mathrm{s})$ & 22.0 & $1.32(3 \mathrm{H}, \mathrm{s})$ & 26.7 & $2.37(1 \mathrm{H}, \mathrm{dd}, J=3.6,12.6 \mathrm{~Hz})$ \\
\hline & & $6.23(1 \mathrm{H}, \mathrm{s})$ & & & & $2.59(1 \mathrm{H}, \mathrm{dd}, J=2.4,12.6 \mathrm{~Hz})$ \\
\hline
\end{tabular}

Chemical shifts in ppm from TMS as internal standard.

${ }^{1} \mathrm{H}$ and ${ }^{13} \mathrm{C}$ NMR were measured at $600 \mathrm{MHz}$ and $150 \mathrm{MHz}$, respectively. 


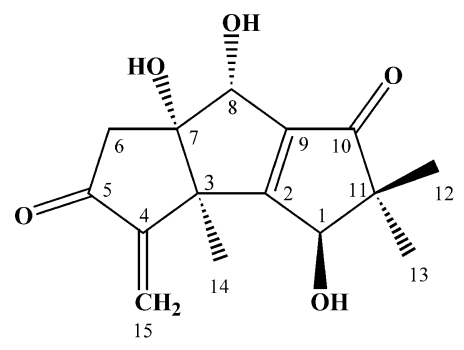

Hirsutenol D (1)

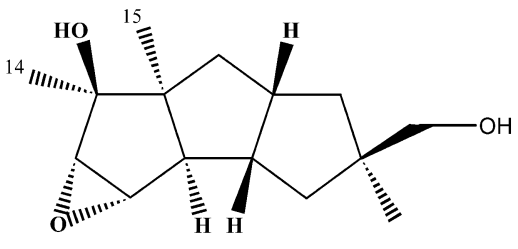

Hirsutenol E (2)

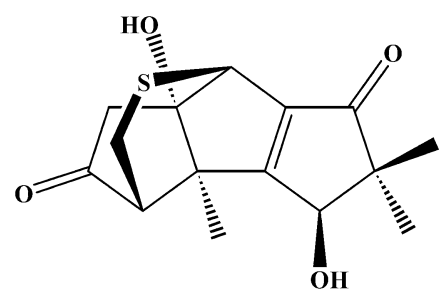

Hirsutenol F (3)

Fig. 1 Structures of hirsutenols D (1), E (2) and F (3).

data are in Table 2. The molecular formula of 1 was determined to be $\mathrm{C}_{15} \mathrm{H}_{18} \mathrm{O}_{5}$ on the basis of high-resolution FAB-MS data $\left[\mathrm{m} / \mathrm{z}\right.$ found $301.1057(\mathrm{M}+\mathrm{Na})^{+}$, calcd 301.1052]. The ${ }^{1} \mathrm{H}$ NMR spectrum of 1 in $\mathrm{CD}_{3} \mathrm{OD}$ exhibited signals due to a terminal methylene at 6.23 and $5.72 \mathrm{ppm}$, two oxygenated methines at 4.60 and $4.44 \mathrm{ppm}$ and three singlet methyls at $1.52,1.11$ and $1.02 \mathrm{ppm}$. In the ${ }^{13} \mathrm{C}$ NMR spectrum, 14 carbon peaks were observed. Direct ${ }^{1} \mathrm{H}-{ }^{13} \mathrm{C}$ connectivity was established by the HMQC experiment and chemical structure was assigned by interpretation of HMBC spectrum. HMBC showed longrange correlations from $\mathrm{H}-1$ to $\mathrm{C}-2, \mathrm{C}-9$ and $\mathrm{C}-10$, from $\mathrm{H}-$ 8 to $\mathrm{C}-2, \mathrm{C}-3$ and $\mathrm{C}-9$, from $\mathrm{H}-12$ and $\mathrm{H}-13$ to $\mathrm{C}-1, \mathrm{C}-10$ and $\mathrm{C}-11$, from $\mathrm{H}-14$ to $\mathrm{C}-2, \mathrm{C}-3, \mathrm{C}-4$ and $\mathrm{C}-7$, and from $\mathrm{H}-15$ to $\mathrm{C}-4$ and $\mathrm{C}-5$. The chemical shift value of $\mathrm{C}-2$ $(185.9 \mathrm{ppm})$ suggested that a remained carbonyl carbon at 208.5 ppm should be placed at C-10 position, which was confirmed by HMBC cross-peaks from $\mathrm{H}-12$ and $\mathrm{H}-13$ to C-10. The above NMR data implied that hirsutenol D was structurally similar to hirsutenol A [4], and thus, the structure of 1 was established by the process of elimination in comparison with hirsutenol A. During the process of elimination, we found that a methylene signal of C-6 was not observed in both proton and carbon NMR spectra and it would seem to be quenched by deuterium exchange in $\mathrm{CD}_{3} \mathrm{OD}$. It is known that hydrogens adjacent to carbonyl carbon are sometimes quenched and this phenomenon was observed in the case of hirsutenol A. It could be confirmed by ${ }^{1} \mathrm{H}-\mathrm{NMR}$ measurement in DMSO- $d_{6}$ after re-exchange of exchangeable protons in methanol. The ${ }^{1} \mathrm{H}$ NMR spectrum that was measured after re-exchange gave an additional methylene proton signal to that measured in $\mathrm{CD}_{3} \mathrm{OD}$. Therefore, the structure of $\mathbf{1}$ was determined as shown in Fig. 1. The relative stereochemistry was determined by the comparison with that of known tricyclic sesquiterpenes and by the aid of NOESY spectrum, which showed NOEs between $\mathrm{H}-1, \mathrm{H}-13$ and H-14. Also no NOEs between H-8 and $\mathrm{H}-1$ and between $\mathrm{H}-8$ and $\mathrm{H}-14$ suggested that $\mathrm{H}-8$ would be placed on anti-plane of $\mathrm{H}-1$ and $\mathrm{H}-14$.
The molecular formula of 2 was established as $\mathrm{C}_{15} \mathrm{H}_{24} \mathrm{O}_{3}$ by high-resolution ESI-MS measurement. The ${ }^{1} \mathrm{H}$ NMR spectrum of $\mathbf{2}$ showed signals attributable to two oxygenated methines at 3.76 and $3.27 \mathrm{ppm}$, four methylenes including one oxygenated methylene, three methines at 2.61, 1.46 and $2.82 \mathrm{ppm}$ and three methyls at $1.32,1.28$ and $1.04 \mathrm{ppm}$, while 15 carbons in the ${ }^{13} \mathrm{C}$ NMR spectrum were observed. Direct ${ }^{1} \mathrm{H}^{13} \mathrm{C}$ connectivity of these signals was established with the aid of an HMQC spectrum, and the structure was assigned by the HMBC spectrum. HMBC showed the critical long-range correlations from $\mathrm{H}-12$ and $\mathrm{H}-13$ to carbons of $\mathrm{C}-1, \mathrm{C}-10$, and $\mathrm{C}-11$, from $\mathrm{H}-1$ to $\mathrm{C}-9$ and $\mathrm{C}-10$, from $\mathrm{H}-2$ to $\mathrm{C}-1, \mathrm{C}-4$ and $\mathrm{C}-7$, from $\mathrm{H}-3$ to $\mathrm{C}-1, \mathrm{C}-4, \mathrm{C}-7$ and $\mathrm{C}-9$, from $\mathrm{H}-4$ to $\mathrm{C}-2, \mathrm{C}-3$ and $\mathrm{C}-5$, from $\mathrm{H}-5$ to $\mathrm{C}-3$ and C-4, from $\mathrm{H}-8$ to $\mathrm{C}-6, \mathrm{C}-7, \mathrm{C}-9$ and $\mathrm{C}-10$, from $\mathrm{H}-14$ to C-5, C-6 and C-7 and from H-15 to C-3, C-6, C-7 and C-8. Thus, compound $\mathbf{2}$ was assigned as a new tricyclic sesquiterpene with an epoxy moiety. The epoxyl group was proposed by large ${ }^{1} J_{\mathrm{CH}}$ coupling constant of $185 \mathrm{~Hz}$ at C-4. The stereochemistry was proposed by the NOESY spectrum, which exhibited the NOE correlations between $\mathrm{H}-2, \mathrm{H}-4, \mathrm{H}-9$ and $\mathrm{H}-1$, and no NOEs between $\mathrm{H}-4$ and $\mathrm{H}-$ 14, H-4 and H-15, H-5 and H-14 and H-5 and H-15, implying that $\mathrm{H}-14$ and $\mathrm{H}-15$ should be placed on the antiplane of H-2, H-4, H-5 and H-9.

The molecular formula of $\mathbf{3}$ was determined to be $\mathrm{C}_{15} \mathrm{H}_{18} \mathrm{O}_{4} \mathrm{~S}_{1}$ by high-resolution FAB-MS data $[\mathrm{m} / \mathrm{z}$ found 295.1001 $(\mathrm{M}+\mathrm{H})^{+}$, calcd 295.1004], and IR absorptions at 3369 and $1746 \mathrm{~cm}^{-1}$ indicated the presence of hydroxyl and carbonyl groups. The ${ }^{1} \mathrm{H}$ and ${ }^{13} \mathrm{C}$ NMR spectra in the aid of the DEPT spectrum suggested that $\mathbf{3}$ was composed of two carbonyl carbons, two $s p^{2}$ quaternary carbons, three $s p^{3}$ quaternary carbons, three methines, two methylenes and three methyls. A partial structure $-\mathrm{CH}_{2}-\mathrm{CH}-$ was established by the interpretation of proton coupling constants, and plenary structure was determined by the $\mathrm{HMBC}$ experiment in combination with the HMQC spectrum. HMBC correlations from $\mathrm{H}-1$ to $\mathrm{C}-2, \mathrm{C}-9$ and $\mathrm{C}-$ 10, from $\mathrm{H}-4$ to $\mathrm{C}-3$ and $\mathrm{C}-5$, from $\mathrm{H}-6$ to $\mathrm{C}-3, \mathrm{C}-5, \mathrm{C}-7$ 

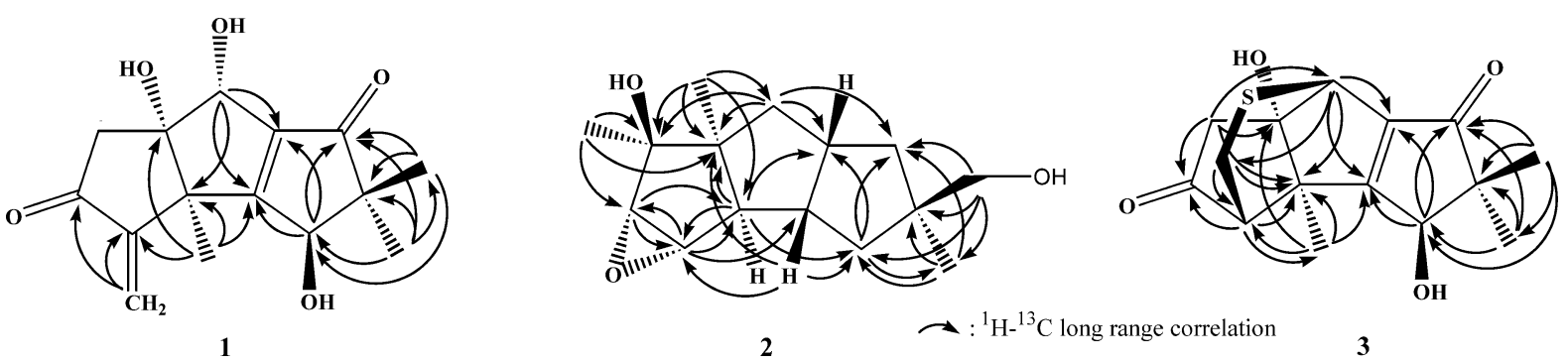

Fig. $2 \mathrm{HMBC}$ correlations of hirsutenols $\mathrm{D}(\mathbf{1}), E(\mathbf{2})$ and $F(\mathbf{3})$.

and $\mathrm{C}-8$, from $\mathrm{H}-8$ to $\mathrm{C}-2, \mathrm{C}-3, \mathrm{C}-6, \mathrm{C}-9$ and $\mathrm{C}-15$, and from $\mathrm{H}-15$ to $\mathrm{C}-3, \mathrm{C}-4$ and C-8 established the structure of 3, as shown in Fig. 2. The relative stereochemistry was determined by a NOESY spectrum, which exhibited crosspeaks between $\mathrm{H}-1$ and $\mathrm{H}-13, \mathrm{H}-4$ and $\mathrm{H}-14$, and $\mathrm{H}-12$ and H-15.

Superoxide radical scavenging activity was assayed by the irradiated riboflavin/EDTA/NBT system with minor modifications [7]. The mixture consisted of $140 \mu \mathrm{l}$ of $0.03 \mathrm{mM}$ riboflavin, $1 \mathrm{mM}$ EDTA, $0.6 \mathrm{mM}$ methionine and $0.03 \mathrm{mM}$ NBT solution in $50 \mathrm{mM}$ potassium phosphate buffer ( $\mathrm{pH} 7.8$ ) and $10 \mu \mathrm{l}$ of sample solutions, which include the test compounds and the reference compounds $(\alpha$-tocopherol and trolox) at various concentrations in $\mathrm{MeOH}$, as well as $\mathrm{MeOH}$ as a control. The photoinduced reactions to generate superoxide anion were carried out in an aluminum foil-lined box with two $20 \mathrm{~W}$ fluorescent lamps. The distance between reactant and lamp was adjusted until the intensity of illumination reached 1000 lux. The reactant was illuminated at $25^{\circ} \mathrm{C}$ for 7 minutes. The photochemically reduced riboflavin generated superoxide anion, which reduced NBT to blue formazan. Reduction of NBT was measured by the absorbance change at $570 \mathrm{~nm}$ before and after irradiation using a microplate. Hirsutenol $\mathrm{F}$ among the compounds tested exhibited the most potent superoxide radical scavenging activity with an $\mathrm{EC}_{50}$ of $0.39 \mathrm{mM}$, which was higher than $\alpha$-tocopherol $(0.71 \mathrm{mM})$ and trolox $(1.56 \mathrm{mM})$ used as control. Hirsutenol E also showed significant scavenging activity against the superoxide radical anion with an $\mathrm{EC}_{50}$ value of $1.62 \mathrm{mM}$, while hirsutenol $\mathrm{D}$ displayed marginal activity with an $\mathrm{EC}_{50}$ value of $8.78 \mathrm{mM}$.

Acknowledgments This work was supported in part by KoreaVietnam Joint Research grants (to J.-P. Kim) and the Korea Health 21 R\&D Project, Ministry of Health \& Welfare, Republic of Korea (A-050432). We thank Mr. Yasuaki Esumi (RIKEN) for obtaining Mass data.

\section{References}

1. Coyle JT, Puttfarcken P. Oxidative stress, glutamate, and neurodegenerative disorders. Science 262: 689-695 (1993)

2. Halliwell B, Gutteridge JMC. Role of free radicals and catalytic metal ions in human disease: An overview. Method in Enzymology 186: 1-85 (1990)

3. Hammond B, Kontos HA, Hess ML. Oxygen radicals in the adult respiratory distress syndrome, in myocardial ischemia and reperfusion injury, and in cerebral vascular damage. Can J Physiol Pharmacol 63: 173-187 (1985)

4. Yun BS, Lee IK, Cho YR, Cho SM, Yoo ID. New tricyclic sesquiterpenes from the fermentation broth of Stereum hirsutum. J Nat Prod 65: 786-788 (2002)

5. Yun BS, Cho YR, Lee IK, Cho SM, Lee TH, Yoo ID. Sterins $\mathrm{A}$ and B, new antioxidative compounds from Stereum hirsutum. J Antibiot 55: 208-210 (2002)

6. Yoo NH, Yoo ID, Kim JW, Yun BS, Ryoo IJ, Yoon ES, Nguyen TC, Kim JP. Sterin C, a new antioxidant from the mycelial culture of the mushroom Stereum hirsutum. Agric Chem Biotechnol 48: 38-41 (2005)

7. Beauchamp C, Fridovich I. Superoxide dismutase: improved assays and an assay applicable to acrylamide gels. Anal Biochem 44: 276-287 (1971) 